\title{
Fascial Fibroma
}

National Cancer Institute

\section{Source}

National Cancer Institute. Fascial Fibroma. NCI Thesaurus. Code C66764.

A benign fibrous tumor arising from the fascial connective tissue. 